\title{
Travel Expenses In Connection With Tax-Deductible Education Expenses
}

William A. Bottiglieri, MBA, CPA, JD, Iona College, New Rochelle, NY, USA Patrick J. Reville, JD, Iona College, New Rochelle, NY, USA

\begin{abstract}
Trade or business expenses are deductible if they are ordinary and necessary with respect to the trade or business in which they were incurred. Treasury Regulations bring education expenses into this purview but only if they maintain or improve skills already acquired or allow a taxpayer to maintain his current position. Related travel expenses in connection with educational activities may come into play in (i) travel to an out of town location to attend an educational function, (ii) travel while engaging in educational activities or (iii) travel which is itself a form of education. Current regulations may limit the allowable deduction for these education-related travel expenses.
\end{abstract}

Keywords: Deductible Educational Expenses; Deductible Trade Or Business Expenses; Educational Travel Expenses; IRC 162

\section{INTRODUCTION}

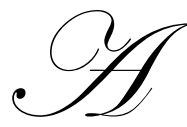

deduction for education expenses is permitted under Sec. 162 of the Internal Revenue Code of 1986, as amended (IRC). Under the proper circumstances such expenses are considered trade or business expenses which are allowable as deductions under Subsection A of IRC 162, as expanded by Treasury Regulation 1.162-5, which provides the authority and guidance for the deduction of education expenses.

For purposes of determining the deduction for trade or business expenses, including education expenses, one must be presently engaged in a trade or business, either as a separate business entity such as a corporation or as a sole proprietor. However, an employee is also considered to be engaged in a trade or business, i.e. the trade or business of performing the services he renders at his place of work. Accordingly, when we refer to teachers, they are considered to be engaged in the trade or business of teaching. This allows what is commonly referred to as employee business expenses to come within the ambit of IRC 162 and the related regulations and IRS positions (Rev. Rule 6097). However, a taxpayer who is not currently employed or not otherwise engaged in a trade or business is not entitled to a trade or business deduction, even for qualifying expenses (Rev. Rule 60-97). For a teacher, he will not be considered to have ceased engaging in his employment while on sabbatical or over a summer break (Rev. Rule 60-97).

In general, a deduction for education expenses is allowable if the education either (a) maintains or improves existing skills required by the individual in his employment or other trade or business or (b) meets the express requirements of the individual's employer to retain, but not obtain, the individual's job status or rate of compensation. Thus, education expenses incurred by an employee are not deductible if the expenses are required in order to meet the minimum requirements for qualification of his intended employment or if the expenses qualify him for a new trade or business. In these cases, the expenses will be treated as personal in nature because they have not been incurred in a trade or business but rather as a means of entering a new trade or business.

Treasury Regulation Sec. 1.162-5 provides the conceptual framework for deducting education expenses with examples of its application. The provisions allowing a deduction apply even though the education may lead to a degree. However, even if education expenses meet the above requirements they will be considered personal and therefore not deductible if they allow the taxpayer to meet the minimum educational requirements of a trade or business or they qualify the taxpayer for a new trade or business (Treas. Reg. 1.162-5(b)). 
The minimum educational requirement with respect to a position in an educational institution is the minimum level of education in terms of degree normally required at the time the individual is hired. An individual will ordinarily be considered to have met the requirements if, for example, he has tenure or his present service is being counted towards tenure. Someone in a provisional or temporary position pending completion of an anticipated degree would not have met the minimum educational requirements and thus could not deduct any educational expenses.

The second category of educational expenses which are not deductible are those which qualify the taxpayer for a position in a new trade or business. Cases in this area indicate that there is a wide range of interpretation in determining what exactly constitutes a new trade or business. However, with respect to teaching, the regulations state that "all teaching and related duties shall be considered to involve the same type of general work" (Treas. Reg. 1.162-5(b)(3)(i)). Examples provided in this section of changes in duties which do not constitute a new trade or business are (i) classroom teacher in one subject to classroom teacher in another subject; (ii) classroom teacher to guidance counselor and (iii) classroom teacher to principal.

The cost of obtaining an advanced degree such as an MBA is generally considered deductible if the taxpayer broadens his expertise within his present field rather than obtains qualifications to enter a new field. The present employment status of the taxpayer is a crucial factor in determining the deductibility of the MBA educational expenses. In the Tax Court memorandum decision in McEwen (TC Memo 2004-107), the taxpayer had been employed by two financial analyst firms after receiving her BBA degree. It was well known that these firms required an MBA for promotion. Had taxpayer continued her employment with either of these firms and sought and received an MBA in an effort to obtain a promotion the costs of the education would clearly had been deductible. However, the taxpayer resigned her position and completed her MBA program at a time when she was unemployed. After receiving her degree she obtained a position with a firm that required the MBA for employment. The court rightfully denied the deduction ruling that she had obtained education which qualified her for a new position which was different from the one previously held. Had the taxpayer returned to her previous employment after receiving her degree, even in an advanced position, the deduction would have been allowed. In most cases MBA candidates are presently working and incur the education expenses at that time. The issue in determining deductibility is whether the education expenses qualify these individuals for a new position or simply improve their current skills. The regulations cite as examples of qualifying courses those which would be considered refresher courses or courses dealing with current developments in taxpayer's field (Treas. Reg. 1.162-5(c)). Courts have held that education need only "enhance the taxpayer's existing skills" and have a direct relationship to the individual's responsibilities.

Where the education expenses are deductible the deduction includes amounts spent for tuition, books, supplies (Treas. Reg. 1.162-5(c)), and reasonable expenses for research and typing (Rev. Rul. 67-421). The several types of travel expenses related to tax-deductible education expenses are (i) local transportation expenses, (ii) travel to an out of town location to attend an educational activity, (iii) travel while engaging in educational activities and (iv) travel which is itself a form of education.

\section{LOCAL TRANSPORTATION}

Local transportation expenses are those which are incurred when one is not in a "travel status". For tax purposes the status of being in travel occurs when one is away from home overnight. The general application of this distinction is that when one can reasonably reach one's destination and return home the same day without requiring a night's rest then the rules for local transportation apply. If however the trip is one which reasonably requires a night's sleep or rest then the taxpayer is in a travel status.

Local transportation expenses incurred in connection with qualifying education activities are included as deductible education expenses. These transportation expenses include the cost of local transportation such as by bus, subway, taxi, etc. as well as the cost of using taxpayer's own car if that case applies. Car expenses are determined either by the actual cost of operation of the car during the specified transportation or by using a standard mileage rate applicable to business travel, currently $\$ .51 / \$ .55$ per mile in 2011 , plus tolls and parking fees. Under no circumstances may the cost of meals be deducted unless they are incurred when taxpayer is in a travel status. 
These local transportation expenses will be deductible if taxpayer's education activities are found to be temporary, i.e. lasting no more than one year. If taxpayer's attendance at school is realistically expected to last for more than one year then the attendance is not temporary and local transportation expenses will not be deductible except under limited circumstances. If the activities are temporary the expenses of taxpayer going from work or home to school and returning are deductible. This is true whether taxpayer travels directly to school from work or first goes home and then to school or even goes to school on non-working days (IRS Pub. 970).

If the education activities are not temporary then the only transportation expenses which may be deducted are those incurred in going directly from work to school. If taxpayer goes home from work and then to school then the expenses which are deductible are limited to the amount that would have been incurred had taxpayer gone directly to school from work.

\section{TRAVEL EXPENSES - IN GENERAL}

Some of the expenses which are deductible as travel expenses include expenses which would otherwise be personal such as meals, lodging, laundry, hotel telephone, etc. The range of allowable travel expenses is broad under the rationale that taxpayer is both maintaining a home at his principal residence and at the same time duplicating certain expenses while away from home overnight. However, taxpayers are not required to prove that they have duplicate living expenses in order to claim these deductions while away from home. As stated previously, a taxpayer is determined to be in a travel status or "away from home overnight" on a trip that would reasonably require sleep or rest in connection with the travel. As stated by the IRS, a taxpayer is in a travel status, i.e. away from home overnight "if his duties require him to be away from the general area of his tax home for a period substantially longer than an ordinary day's work and, during his off time while away, he needs to get sleep or rest to meet the demands of his work" (IRS Pub. 463). As an illustration provided within the literature, taxpayer, a railroad conductor, leaves his home terminal on a regularly scheduled round trip between two cities and returns home sixteen hours later. During this time he has six hours off at his turnaround point where he eats two meals and rents a hotel room to get necessary sleep before starting the return trip. This taxpayer is considered to be away from home and can deduct these expenses which will be considered travel expenses (IRS Pub. 463). Further, the "sleep or rest" rule requires a stop of sufficient duration that one would reasonably incur an increase in expenses such as the securing of lodging. A mere pause in the daily work routine is not sufficient for this purpose. Thus, taxpayer did not satisfy this requirement where he did not secure lodging during his business trips even though he was required to rest during those trips because of a medical condition (Barry v. Com (27 ATR 2D 71-334)). No expenses will be deductible if they are deemed to be lavish or extravagant under the circumstances such as the cost of a deluxe hotel or resort or expensive meals (IRS Pub. 17).

The location of the travel also has a bearing on the amount of the deductible expenses. For travel entirely within the U.S., an allocation between deductible and nondeductible expenses would have to be made if any of the expenses incurred are attributable to personal activities such as sightseeing or social events in addition to the education activities. The actual cost of transporting oneself to and from the location of the activity though is not subject to allocation. Thus, if the primary purpose of the trip was educational, such as to attend a three-day seminar with an added one-day personal pleasure stay, then the entire cost of traveling to and returning from the location of the seminar would be deductible even though taxpayer spent minimal time on personal activities during the trip. Only meals and lodging relating to the educational portion of the trip would be deductible, in addition to the direct costs of attending the seminar, such as registration fees, local transportation to the seminar, etc.. If however the primary purpose of the trip was for personal purposes and taxpayer happened to have attended an educational event such as a seminar while away on this personal trip then the travel cost to the location and the cost of the return trip home would not be deductible. Again though, taxpayer would be able to deduct any direct costs of the business portion of the trip. In either case the local transportation expenses, the meals and lodging are deductible only if they can be attributed to the time spent on educational activities (Reg. 1.162-5(e)(1)).

With respect to foreign travel outside of the United States, if the entire time outside the U.S. is spent on business activities all of the travel expenses of getting to and returning from the business destination are deductible (IRS Pub. 463). This rule holds where the taxpayer has no substantial control over arranging the trip outside the U.S. such as to a conference or convention held during a specific period. Unlike travel expenses incurred entirely within 
the U.S. where a taxpayer can deduct the cost of getting to and from the business destination if the trip is primarily for business purposes, in the case of foreign travel an allocation of all expenses, including travel to and from the location, must be made if both business and personal activities are conducted during the course of the trip. Business days are those in which taxpayer conducts normal business activities during the hours which are normally considered appropriate for business such as from 9 a.m. to 5 p.m. (Reg. 1.274-4(d)). Business days would further include days traveling to and from the business destination (Reg. 1.274-4(d)). The allocation of deductible business expenses is made on a day by day basis by multiplying all of the foreign travel expenses based on the number of business days to total days of the trip.

\section{TRAVEL TO A LOCATION OF EDUCATIONAL ACTIVITIES}

The above rules apply without modification to travel expenses incurred in getting to and returning from an out-of-town location at which deductible education expenses are incurred. These travel expenses, including meals and lodging, incurred on a trip undertaken primarily to attend educational activities are deductible as education expenses. If away-from-home travel is taken primarily to get education that qualifies for deduction under the rules discussed above, all costs of travel, meals and lodging incurred in connection with that education are deductible, except that part that's allocable to personal activities, such as sight-seeing, social visiting, recreation, etc. For example, a taxpayer who works in New York City traveled to Miami to attend, and did attend, a deductible oneweek course at the request of his firm. While in Miami he took a sight-seeing trip for a day. Since the trip was primarily for business, he can deduct his round-trip airfare to Miami, but he can't deduct his transportation expenses for the sight-seeing trip. Only the travel to Miami and the meals and lodging connected with his educational activities can be claimed as educational expenses.

On the other hand, if the purpose of the trip is primarily personal, only the cost of meals and lodging during the time spent while participating in deductible educational pursuits is deductible. Time spent on personal activities as compared with time spent on business education is the principal factor in determining the primary purpose of the trip. For example, a taxpayer, who works in Detroit, traveled to New York to take a deductible oneweek seminar. While there he spent an additional three weeks on personal activities. These facts indicate that taxpayer's primary purpose was to take a vacation. He can't deduct his round-trip airfare or his meals and lodging for the three. He can deduct only his expenses for meals and lodging for the one week he attended the seminar.

\section{TRAVEL WHILE ENGAGING IN EDUCATIONAL ACTIVITIES}

Internal Revenue Code Section 274(h)(1) specifically address the issue of seminar cruises and similar trips as education expenses. This section will not allow any education expense deduction for these expenses which are incurred outside of North America unless the taxpayer establishes that the meeting is directly related to the active conduct of taxpayer's trade or business, as has been illustrated thus far. Further, it must be as reasonable for the meeting to be held outside of North America as within North America. Some of the factors to be considered in connection with this determination are the purpose of the meeting and the activities taking place at the meeting, the residences of the members of the sponsoring organization and the locations at which other meetings of the organization have been held. This is a heavy burden for educational activities which could as well have been held in North America as outside North America. In Reuben, (1961) 35 TC 566, a Mediterranean cruise was the site of a medical seminar. In its decision the Court noted that the seminar was given over an eighteen day cruise by five professors with affiliations with Duke University School of Medicine. The cruise however was arranged by a travel agency, Duke University was not officially a party to the seminar and received no fees or compensation for this cruise and the certificate of completion for the seminar was signed by the individual lecturers. Instead the lecturers received free passage on the cruise. The Court further noted that the brochure advertising the cruise consisted of eight pages, only one of which was devoted to the proposed medical program with the balance containing attractive pictures of the area to be visited and other attractive vacation sites. The Court concluded that the taxpayer participated in the cruise primarily because of pleasure considerations and only secondarily for educational purposes and thus allowed only $12 \%$ of the cost of the cruise as a deductible educational expense because only $12 \%$ of the trip was allocable to lectures and coursework. 
Hier v. U.S., (1964, DC CA) 13 AFTR 2d 1043 the district court disallowed a deduction for a "study cruise" of the South Pacific. It held that taxpayers, husband and wife high school teachers, failed to prove that a 21day cruise on which no classes were held on days on which the ship was in port wasn't primarily for personal purposes.

\section{TRAVEL AS A FORM OF EDUCATION}

Internal Revenue Code Section $274(\mathrm{~m})(2)$ provides specifically that no deduction shall be permitted for travel which is itself a form of education. This provision denies a deduction for the expenses of travel as a form of education even though the travel may be directly related to the taxpayer's duties. This rule prevents a deduction when the travel itself is to serve as educational rather than traveling to a place for an educational event. For example, IRS Publication 970 (2009) contains the example of a language teacher who travels through France while on sabbatical to improve her knowledge of the French language and French culture. Her itinerary is carefully selected to attend activities which will improve her language skills and although she spends most of the time visiting French schools and families and attending cultural events these travel expenses are not deductible as educational expenses.

Following this general rule, the Tax Court denied an English teacher a deduction for traveling to places in Europe which she claimed gave her new insights into the material she taught for the benefit of her students (Garcia, TC Summary Opinion 2005-2) and the IRS did not allow the claimed deduction by a speech and drama teacher for expenses on sabbatical leave for travel to various countries to visit theater productions in various localities in order to study various teaching methods (IRS letter Ruling 8950016).

In a frequently cited tax court case, taxpayer was an English teacher who traveled to Greece and Southeast Asia for university extension courses which she took primarily to enhance her skills in her teaching position. The courses had clear educational purposes beyond mere travel, were given by University professors and included tours of related sites and significant reading assignments so that the education consisted of activities other than travel itself. Needless to say there were significant elements of personal activities during the trip. However, the taxpayer spent at least five hours a day on course work during seventeen of the eighteen days of the trip. The Court considered this fact crucial in characterizing the trip as one for primarily educational rather than personal purposes. Despite taxpayer's ancillary personal activities all of her travel expenses were deductible except for minimal personal costs (Jorgensen, 2000, TC Memo 2000-138).

\section{AUTHOR INFORMATION}

William A. Bottiglieri, MBA, CPA, JD, is a Professor in Accounting at Iona College, New Rochelle, New York and is in private practice as an attorney and tax accountant. E-mail: wbottiglieri@iona.edu. Corresponding author.

Patrick J. Reville, JD, is an Associate Professor in Business Law at Iona College, New Rochelle, New York and is in private practice as an attorney. E-mail: preville@iona.edu

\section{REFERENCES}

1. $\quad$ Barry v. Com (27 ATR 2D 71-334)

2. Garcia, TC Summary Opinion 2005-2

3. Hier v. U.S., (1964, DC CA) 13 AFTR 2d 1043

4. Internal Revenue Code of 1986, as amended (IRC), Sec. 162

5. IRC Section 274(h)(1)

6. IRC Section 274(m)(2)

7. IRS letter Ruling 8950016

8. IRS Pub. No. 463 (2010)

9. IRS Pub. No. 970 (2009)

10. IRS Pub. No17 (2011)

11. Jorgensen, 2000, TC Memo 2000-138

12. McEwen (TC Memo 2004-107) 
13. Reuben, (1961) 35 TC 566

14. Rev. Rul. 67-421, 1967-2 CB 84

15. Rev. Rule 60-97, 1960-1 CB 69

16. Treas. Reg. 1.162-5(a)

17. Treas. Reg. 1.162-5(b)

18. Treas. Reg. 1.162-5(b)(3)(i)

19. Treas. Reg. 1.162-5(c)

20. Treas. Reg. 1.162-5(e)(1)

21. Treas. Reg. 1.274-4(d).

22. Treasury Regulation 1.162-5 